Historic, Archive Document

Do not assume content reflects current scientific knowledge, policies, or practices. 



\section{3) THE GREAT BASIN TENT CATERPILLAR} IN NEW MEXICO; LIFE HISTORY, PARASITES, DISEASE, AND DEFOLIATION

by Milton J. Stelzer

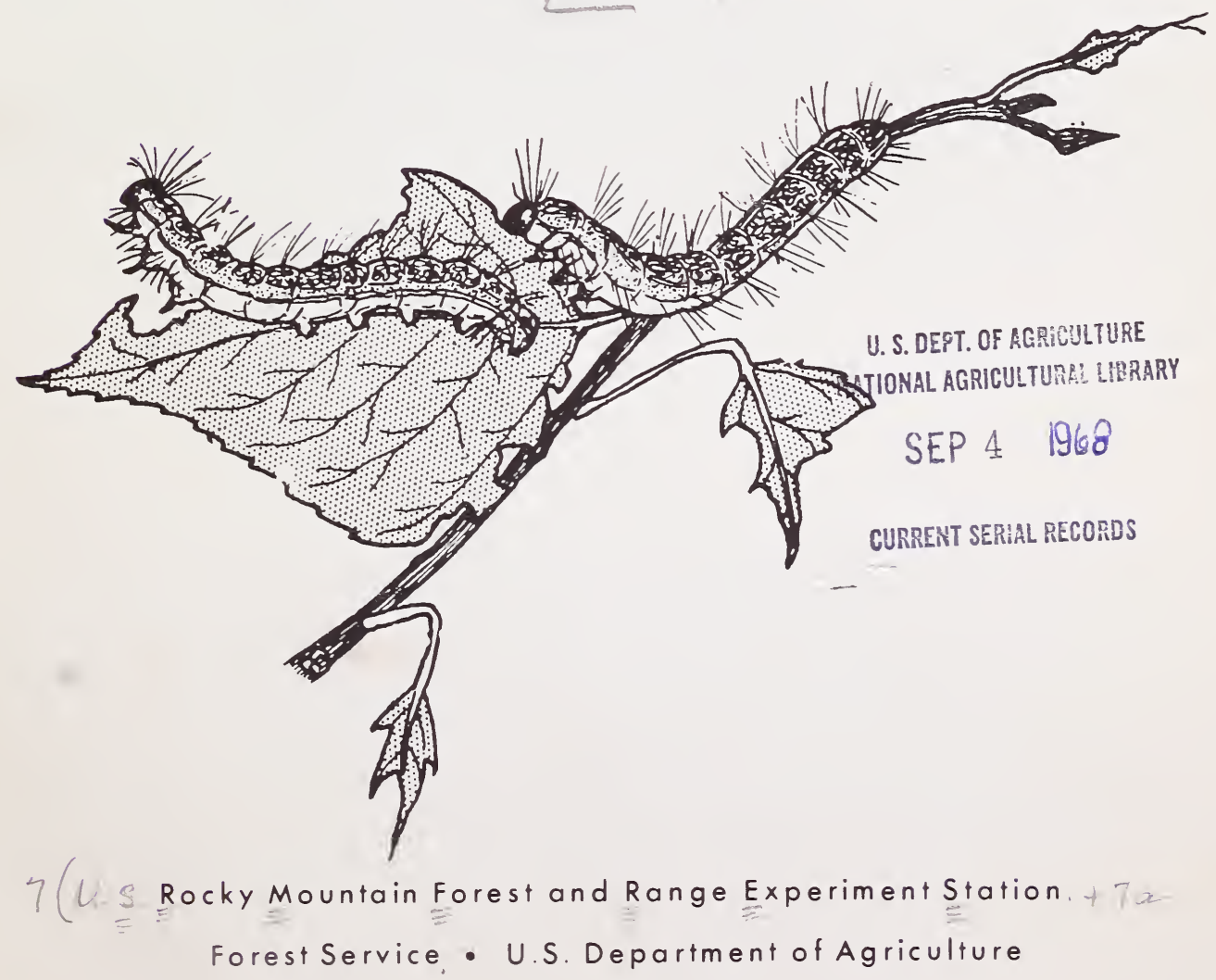



The Great Basin Tent Caterpillar in New Mexico:

Life History, Parasites, Disease, and Defoliation

$$
\text { \& by }
$$

Milton J. Stelzer, Entomologist

Rocky Mountain Forest and Range Experiment Station ${ }^{2}$

${ }^{1}$ The assistance of the personnel of the Insect Identification and Parasite Introduction Branch, Agricultural Research Service, U. S. Department of Agriculture, for identification of the parasites and predators is gratefully acknowledged. Trade names and company names mentioned are for the benefit of the reader and do not imply endorsement or preferential treatment by the U. S. Department of Agriculture.

${ }^{2}$ Central headquarters maintained at Fort Collins, in cooperation with Colorado State University; research was conducted at the Station's project location at Albuquerque, in cooperation with the University of New Mexico. Stelzer is now with United Nations Rhinoceros Beetle Control Project, Western Samoa. 


\section{CONTENTS}

Page

Description of insect stages . . . . . . . . . . 1

Life history and habits . . . . . . . . . . . 4

Study plots . . . . . . . . . . . . . 5

Population trends. . . . . . . . . . . . . 6

Effects of tent caterpillar defoliation on aspen growth . 8

Natural control . . . . . . . . . . . . . 9

Parasites and predators . . . . . . . . . . 9

Eggs • . . . . . . . . . . . . . . . . 9

Larvae . . . . . . . . . . . . . . . . 9

Pupae . . . . . . . . . . . . . . . . 9

Microbial control . . . . . . . . . . 13

Literature cited . . . . . . . . . . . . 16 


\title{
The Great Basin Tent Caterpillar in New Mexico: Life History, Parasites, Disease, and Defoliation
}

\author{
Milton J. Stelzer
}

\begin{abstract}
Epidemics of the Great Basin tent caterpillar, Malacosoma fragile (Stretch), have occurred at periodic intervals over widespread areas from the eastern slope of the Rocky Mountains to the Sierra Nevada-Cascade Ranges. List (1934) reported more than a million acres of aspen and similar trees were defoliated by this pest in southern Colorado during 1934. Aerial surveys in northern New Mexico showed an estimated 140,000 acres of quaking aspen (Populus tremuloides Mich.) were infested in

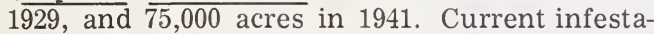
tions have been in epidemic proportions throughout the aspen type in northern New Mexico since 1955 (fig. 1). The widespread occurrence of dead and dying trees over areas heavily defoliated several consecutive years is undoubtedly related to the activity of this pest.

The tent caterpillar is a voracious feeder on many deciduous species of trees and shrubs. At elevations above 8,000 feet, quaking aspen is the favored host; from 1,800 to 3,500 feet, infestations are most serious on cottonwood (Populus spp.) and willow (Salix spp.), especially in recreational areas. The caterpillars will feed on orchard trees such as apple (Malus spp.), pear (Pyrus spp.), plum (Prunus spp.), and cherry (Prunus spp.) when available. They also feed on ceanothus (Ceanothus spp.), wild plum (Prunus spp.), wild cherry (Prunus spp.) bitterbrush (Purshia sp.) oaks Quercus spp.), mountainmahogany (Cercocarpus spp.), and gooseberry (Ribes spp.)

Studies to determine the life history and habits of this pest on quaking aspen were initiated on the Carson National Forest in northern New Mexico during 1960. The identity and importance of parasites were studied, in addition to the effects of defoliation on growth of the host.
\end{abstract}

Figure 1.--Widespread defoliation of quaking aspen in northern New Mexico during active infestation by Malacosoma fragize.

\section{Description of Insect Stages}

The moth of the Great Basin tent caterpillar is a stout-bodied, strong flier. The coloration is quite variable, ranging from pale yellow to light grayish brown, or to a dark reddish brown. The males are generally darker than the females. Wing expanse ranges from 25 to $35 \mathrm{~mm}$. for the males and from 35 to $45 \mathrm{~mm}$. for the females. Two oblique lines divide the forewings into three sectors or bands (fig. 2A).

The eggs, laid in masses containing 60 to 250 eggs, are oval in shape with tapered margins, and only partially encircle the twig (fig. 2B). The eggs are cemented together and covered by a silvery colored, frothy material termed spumaline (Hodson and Weinman 1945) that turns gray to brown with time.

When first hatched, the larvae are about $3 \mathrm{~mm}$. long, nearly uniformly black, with whitish body hairs. The mature larvae are 38 to 50 $\mathrm{mm}$. long. The head capsule and sides of the body are pale blue, with a pale blue stripe down the middle of the dorsum bordered on each side by a black stripe interlaced with varying quantities of orange. The light brownish body hairs are conspicuous. On each segment within the pale blue lateral stripes are two fairly prominent black spots and numerous small interspersing black specks (fig. 2C). 
Figure 2.--Stages of development of the Great Basin tent caterpizzar:

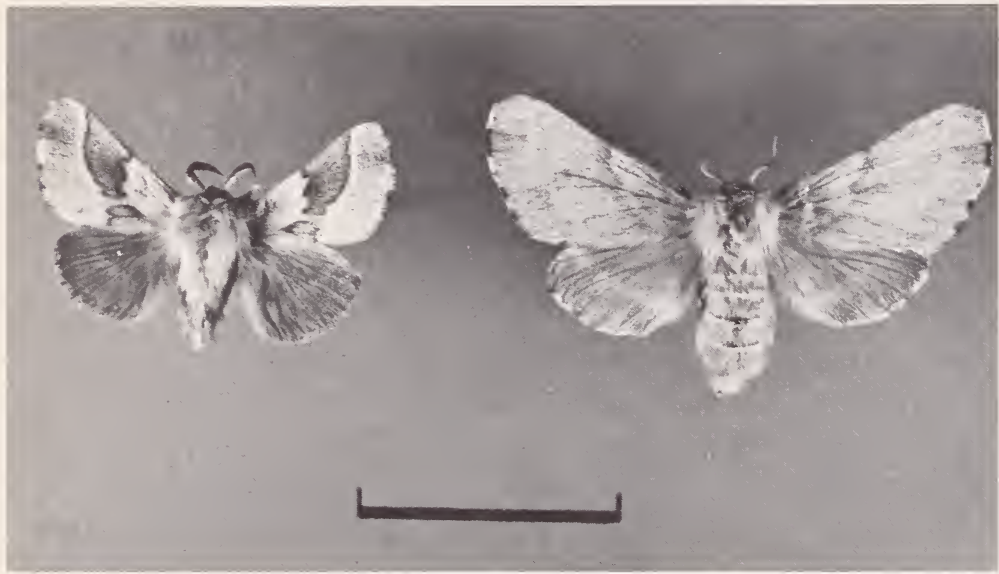

A, Aduzts, Male (Zeft)

and Female (right).

(Scale line = 1 inch)

B, Egg masses

(Scale line = 1 inch)
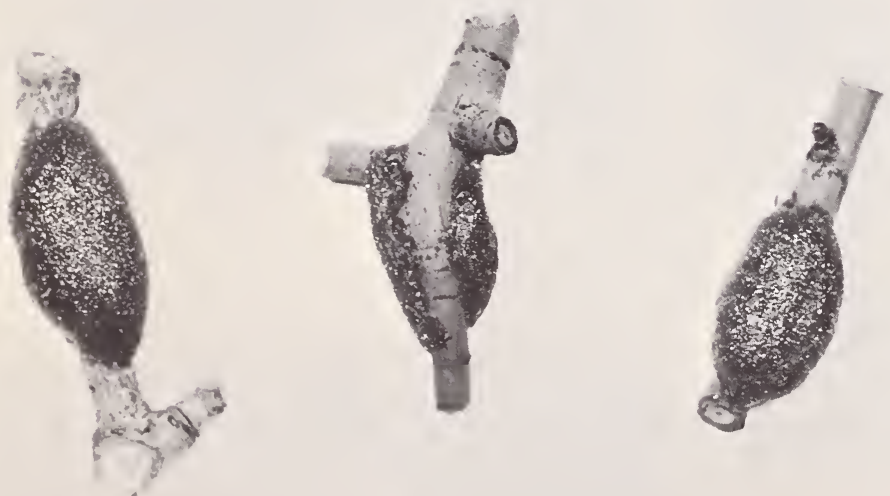
C, Eull-grown

Zarvae

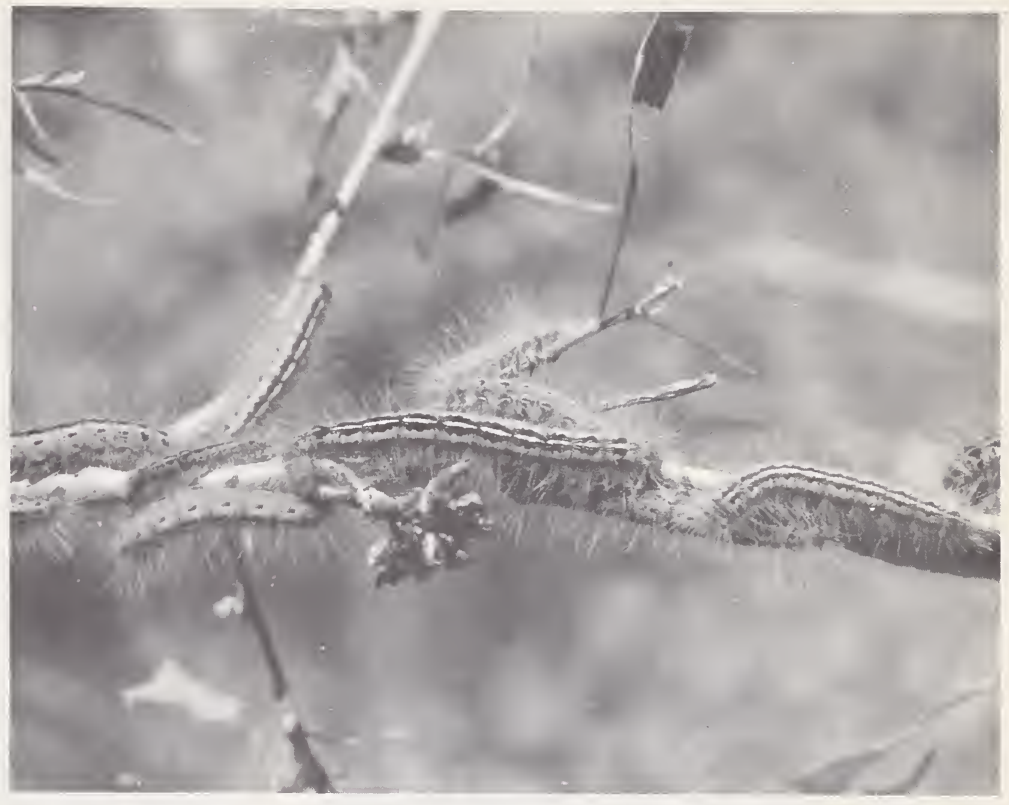

D, Cocoons

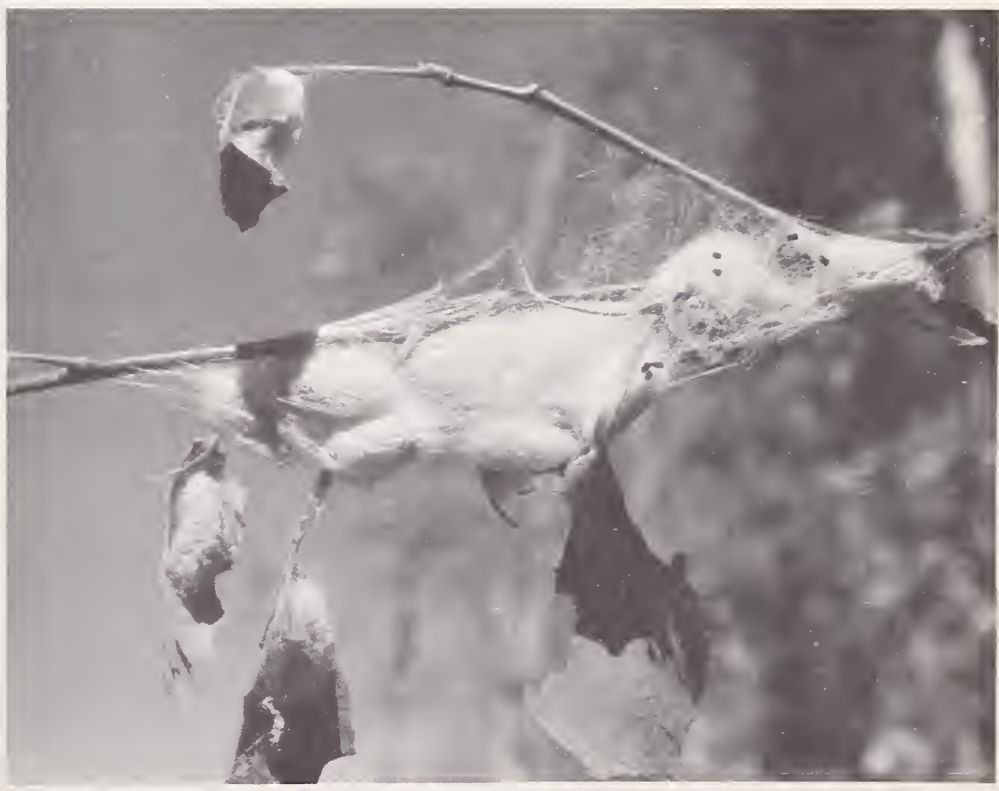


The pupae are 18 to $25 \mathrm{~mm}$. long, dark reddish brown to black in color. They are enclosed in oval cocoons 25 to $40 \mathrm{~mm}$. long of whitish silk impregnated with a yellowish powder (fig. 2D).

Pupal sex can be determined with a high degree of reliability on a weight basis. A frequency polygon of the weight of 80 male and 95 female pupae is presented in figure 3 . Using $330 \mathrm{mg}$. as a division point, with those higher called females and less males, only 4 percent of the pupae would have been incorrectly sexed.

\section{Life History and Habits}

M. fragile has a 1-year life cycle. In northern $\bar{N}$ ew Mexico adult flight and egg deposition takes place from mid-July to early August. Embryonic development is completed within 3 to 4 weeks; the insect then passes the winter as fully formed first-instar larvae within the egg chorion. The larvae start to hatch the following spring, at about the same time the aspen leaf buds begin to swell. Under normal conditions hatch is 90 percent completed in 2 to 3 days. The date of larval hatch ranged from May 16 to 23 during the years from 1961 to 1964 . Upon emergence the larvae from an

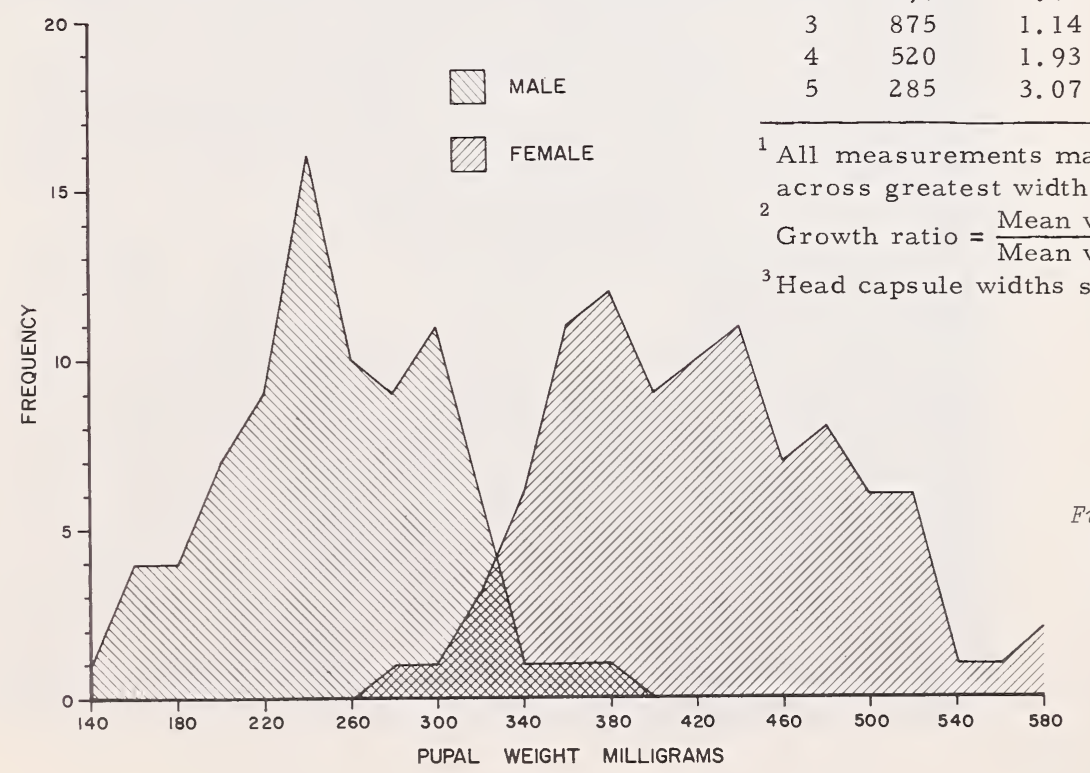

egg mass feed gregariously and begin construction of a silken tent in a nearby crotch, enlarging it as development proceeds. The tent serves as a resting place between forages for food, as a molting site, and also as a place of protection during periods of unfavorable temperatures and humidity. Progeny from several egg masses on the same twig may combine in the construction of a single tent. For example, 74 egg masses were counted on 24 small aspens (up to 12 feet in height) prior to hatch during the spring of 1961 . Reexamination of the trees 1 week after hatch showed 62 tents being constructed. Two weeks after hatch, the larvae had consolidated on only 34 tents and the others abandoned.

A frequency distribution prepared from head capsule measurements on larvae collected during 1961, 1962, and 1963 showed five distinct larval instars (table 1 ).

Table 1. - -Head capsule widths ${ }^{1}$ of the five instars of Malacosoma fragile larvae over a 3 -year period, 1961-63

\begin{tabular}{|c|c|c|c|c|c|}
\hline \multirow{2}{*}{ Instar } & \multirow{2}{*}{$\begin{array}{c}\text { Number } \\
\text { examined }\end{array}$} & \multirow{2}{*}{$\begin{array}{l}\text { Mean } \\
\text { width }\end{array}$} & \multicolumn{2}{|c|}{ Range } & \multirow{2}{*}{$\begin{array}{l}\text { Growth } \\
\text { ratio }\end{array}$} \\
\hline & & & $\begin{array}{l}\text { Mini - } \\
\text { mum }\end{array}$ & $\begin{array}{l}\text { Maxi - } \\
\text { mum }\end{array}$ & \\
\hline \multicolumn{6}{|c|}{$---\underline{\mathrm{mm}} \cdot-\cdots$} \\
\hline 1 & 75 & 0.44 & $\left({ }^{3}\right)$ & -- & -- \\
\hline 2 & 297 & .72 & 0.55 & 0.88 & 1.64 \\
\hline 3 & 875 & 1.14 & .96 & 1.34 & 1.58 \\
\hline 4 & 520 & 1.93 & 1.65 & 2.31 & 1.69 \\
\hline 5 & 285 & 3.07 & 2.42 & 3.41 & 1.59 \\
\hline
\end{tabular}

${ }^{1}$ All measurements made to nearest $0.03 \mathrm{~mm}$. across greatest width of head capsule. Growth ratio $=\frac{\text { Mean width at given instar }}{\text { Mean width at previous instar }}$ ${ }^{3}$ Head capsule widths showed no variation.
Figure 3.--Frequency polygon on male and female pupal weights. Great Basin tent caterpizzar. 
Table 2. --Rate of development of Malacosoma fragile during 1961

\begin{tabular}{|c|c|c|c|c|c|c|c|c|}
\hline \multirow{2}{*}{$\begin{array}{l}\text { Developmental } \\
\text { stage }\end{array}$} & \multicolumn{2}{|c|}{ May } & \multicolumn{4}{|c|}{ June } & \multicolumn{2}{|c|}{ July } \\
\hline & $\begin{array}{c}24 \\
\text { (hatch) }\end{array}$ & 31 & 8 & 15 & 22 & 29 & 5 & 29 \\
\hline Instar 1 & 100.0 & 0.6 & & & & & & \\
\hline 2 & & 64.1 & 1.5 & & & & & \\
\hline 3 & & 33.0 & 79.2 & 0.3 & & & & \\
\hline 4 & & 2.3 & 19.3 & 77.4 & 7.1 & & & \\
\hline 5 & & & & 22.3 & 71.4 & 21.4 & 9.8 & \\
\hline Pupae & & & & & 21.5 & 78.6 & 90.2 & 21.0 \\
\hline Adult & & & & & & & & 79.0 \\
\hline
\end{tabular}

The proportion of larvae in a given instar was determined at weekly intervals during 1961 (table 2). These data indicate the length of the developmental period of $M$. fragile larvae increases with maturity. While almost 70 percent of the larvae were in the third instar within 2 weeks after hatch, fourth- and fifth-instar larvae were present in collections taken over a period of 4 weeks. The period of larval development ranged from about 30 to 42 days.

At maturity the larvae lose their gregarious habit, and wander at random over the host and other tree species or on the ground, seeking a site for pupation. Two to three days are spent spinning the cocoon and in the prepupal stage. Adults emerge from 12 to 18 days later. Mating and oviposition were noted from July 14 to August 1 during 1961. In several instances, mating was observed before the female moth had inflated her wings. Each female ordinarily produces only one egg mass. Live twigs under three-fourths inch in diameter are the preferred sites for egg deposition. New egg masses were never found on dead twigs.

\section{Study Plots}

A series of circular plots, one-fortieth acre in size, were established in six aspen stands on the Carson National Forest within a 60 -squaremile area in northern New Mexico during 1961. The stands were selected so that they represented recent, intermediate, and old infestations of $\underline{\mathrm{M}}$. fragile (table 3 ).
The plots served as reference points for annual egg mass survey counts, defoliation estimates, the collection of pupae for parasite rearing, identification, and evaluation studies, and other biological observations. At the time they were established in 1961, all the trees over 4 inches diameter breast height (d.b.h.) were classified as to their condition: alive, dead, or alive but showing some top-kill. Increment borings from the trees were used to determine effects of defoliation on radial growth.

Table 3.--Characteristics of six aspen stands and distribution of the thirty 1/40-acre plots used in studies of the biology of Malacosoma fragile

\begin{tabular}{|c|c|c|c|c|}
\hline Stand & Area & Plots & $\begin{array}{c}\text { Trees over } \\
4 \text { inches } \\
\text { d. b.h. }\end{array}$ & Elevation \\
\hline & Acres & No. & No./acre & Feet \\
\hline $\mathrm{A}$ & 150 & 4 & 630 & 10,000 \\
\hline B & 100 & 10 & 620 & 9,900 \\
\hline $\mathrm{C}$ & 20 & 4 & 560 & 9,650 \\
\hline $\mathrm{D}$ & 100 & 3 & 535 & 9,500 \\
\hline $\mathrm{E}$ & 500 & 5 & 640 & 9,500 \\
\hline$F$ & 500 & 4 & 670 & $\begin{array}{l}9,400- \\
9,700\end{array}$ \\
\hline
\end{tabular}




\section{Population Trends}

Egg mass surveys were conducted in August after egg deposition to indicate population trends in the six stands. A minimum of 20 trees were sampled in each stand (usually 5 trees on each plot) by cutting two 30 -inch branches from the upper crown with a pole-pruner. New egg masses on the two branches were tallied, and an average value per tree determined for each stand. Stand defoliation was estimated the following year, usually at the same time the stands were sampled for new egg masses (table 4). Three classes were used to define the level of defoliation:

Light (L).- - Very light feeding damage confined to the tops of the trees. No trees showing complete defoliation.
Moderate (M).-Most trees with approximately 50 percent of the foliage stripped, and scattered trees completely defoliated.

Heavy (H). - Trees completely defoliated.

Stands A, B, and C suffered 4 consecutive years of heavy defoliation. Egg mass counts increased regularly through the 1962 survey in stands $A$ and $B$ before dropping sharply in 1963 and 1964. Egg mass counts, although always high, declined slightly in stand $\mathrm{C}$ from 1961 to 1963 . These sharp declines in egg mass counts in 1963 and 1964 were the result of widespread starvation of the larvae during the fifth instar. Some larval mortality, caused by a naturally occurring nuclear-polyhedrosis virus, was observed in all three stands in 1960 (fig. 4). Periodic examinations of randomly collected tents in 1960, 1961, and 1962 showed, however,

Table 4. --Average number of new egg masses per two 30-inch branches cut from upper crown of each of at least 20 trees in six aspen stands, and degree of defoliation the following year $(Y+1)$

\begin{tabular}{l|c|c|c|c|c|c|}
\hline \multirow{2}{*}{$\begin{array}{c}\text { Stand } \\
\text { and } \\
\text { condition }\end{array}$} & \multicolumn{5}{|c}{ Year sampled (Y) } \\
\cline { 2 - 6 } & 1959 & 1960 & 1961 & 1962 & 1963 & 1964 \\
\hline
\end{tabular}

Stand A:

Number of egg masses

Degree of defoliation $(Y+1)$

Stand B:

Number of egg masses

Degree of defoliation $(Y+1)$

Stand C:

Number of egg masses

Degree of defoliation ( $Y+1)$

Stand D:

Number of egg masses

Degree of defoliation $(Y+1)$

Stand E:

Number of egg masses

Degree of defoliation $(Y+1)$

Stand F:

Number of egg masses

Degree of defoliation $(Y+1)$

$\begin{array}{ccc}-- & -- & 1.79 \\ \mathrm{H}^{1} & \mathrm{H} & \mathrm{H}\end{array}$

$\mathrm{H}$
8.58

$\mathrm{H}$

1.80
$\left({ }^{2}\right)$

$\left({ }^{2}\right)$
1.00

$\left({ }^{2}\right)$

$\begin{array}{rrrrrr}-- & 3.84 & 7.45 & 10.61 & 2.50 & 1.30 \\ \mathrm{H} & \mathrm{H} & \mathrm{H} & \mathrm{H} & \left(^{2}\right) & \left(^{2}\right)\end{array}$

$--\quad--\quad 7.31$

6.41

$\mathrm{H}$

5. 00

0

$\mathrm{H} \quad \mathrm{H} \quad\left({ }^{2}\right) \quad\left({ }^{2}\right)$

\section{$\left.{ }^{2}\right)$}

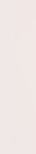


Figure 4.--

Characteristic position and appearance of virus-killed tent caterpizlar Zarvae on the webbing of a tent.

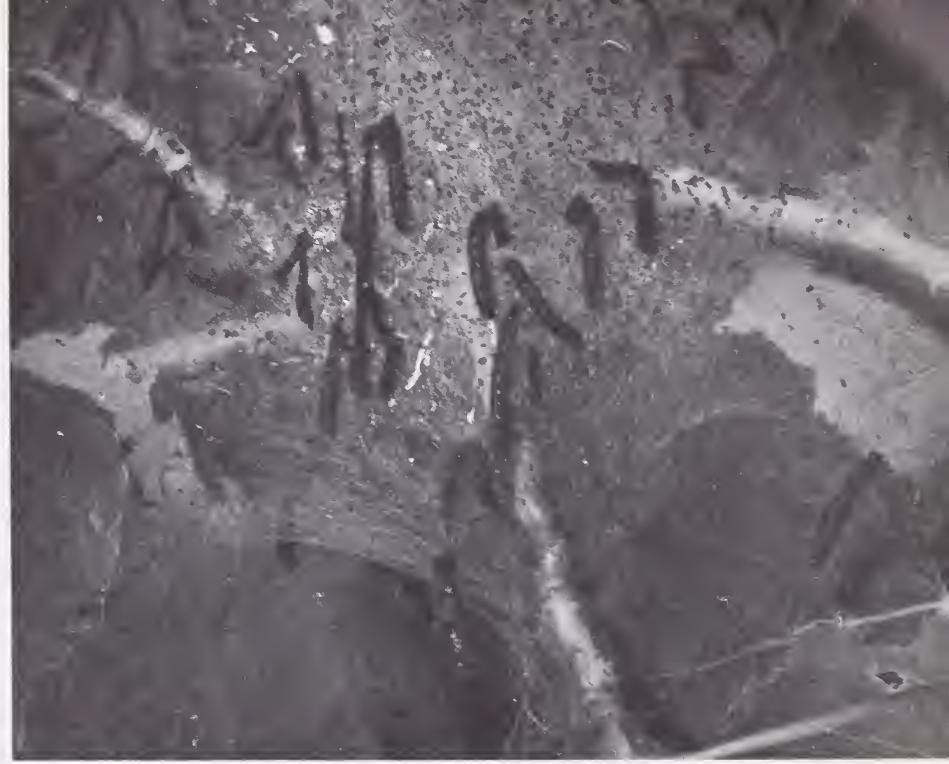

that the incidence of infected colonies-colonies that contained at least one virus-killed larvanever exceeded 20 percent.

Progressive increases in egg mass counts were accompanied by increased levels of defoliation through the summer of 1963 in stand D. During the summer of 1963 a natural virus epizootic occurred at about the time the tent caterpillar larva were starting to pupate. Viruskilled larva were present on almost every tent, as well as on the trunks and branches of the host trees. Some larvae also starved since the stand was completely defoliated several days before pupae were found in the area. Probably a physiological stress of the larvae resulting from the shortage of food available at this critical period of development-just as the larvae were entering the pupal stage-was instrumental in the sudden and extensive appearance of the polyhedrosis. Only scattered colonies containing a few larvae could be found in 1964, and the infestation collapsed.

A similar trend in egg mass counts and subsequent defoliation occurred in stand $\mathrm{E}$. Heavy defoliation was expected in 1964, based on the egg mass counts of the previous fall. Defoliation was only light, however, and few tent caterpillar colonies could be found. The reason for the decline and eventual termination of the $M$. fragile infestation in this stand in 1964 is not entirely clear. Larval starvation was not a factor, as the stand never suffered more than moderate defoliation. It is significant that an earlier outbreak of the tent caterpillar was treated with an aerial application of nuclearpolyhedrosis virus at the rate of 30 billion polyhedra per acre in 1958. From 40 to 50 percent larval mortality was observed the year of treatment (Thompson 1958), and no evidence of the tent caterpillar was found in the stand in 1959. Many larvae collected from this area in 1964 succumbed to virus when attempts were made to rear them in the laboratory.

The infestation at stand $F$ was first detected on June 12, 1961, at which time the larvae were in the third instar, and the trees had suffered 50 percent defoliation. One week later the trees were completely stripped, and migrating larvae searching for food were everywhere. Viruskilled larvae (primarily fifth instar) were found on 50 percent of a series of tents examined in the stand. Although many additional larvae died of starvation, adult survival was sufficient to produce an average of 6.23 egg masses per two 30 -inch branch samples (table 4 ). Counts this high would normally result in complete defoliation of a stand. Defoliation was only moderate in 1962 because the virus infection increased ( 80 percent of tents with virus-killed larvae) and reached its peak when the larvae were in the third instar. Egg mass counts dropped to 1.40 masses per sample unit in 1962. Only light defoliation in scattered pockets occurred in 1963, and egg counts fell to 0.75 . The recurrence of virus infection was the primary factor responsible for the collapse of this infestation. 


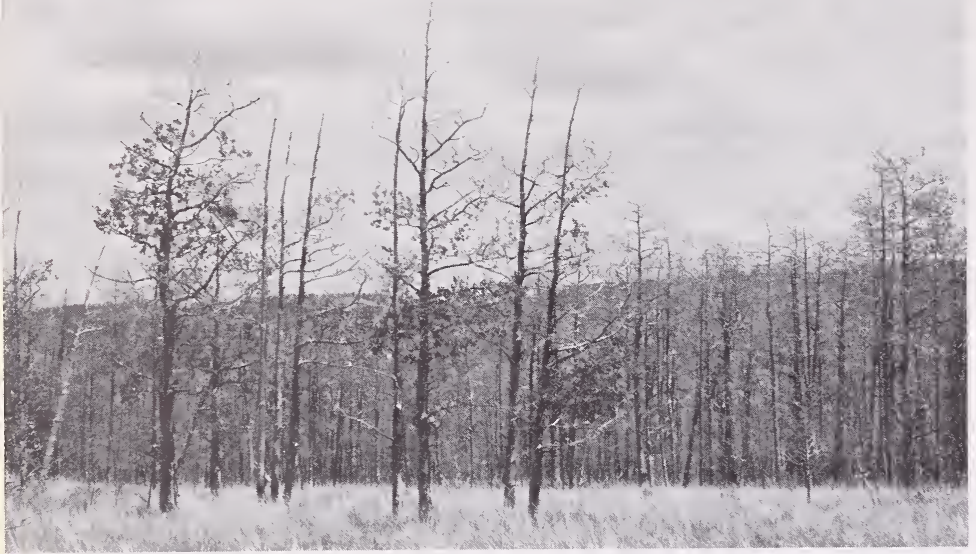

Figure 5.--Deteriorated quaking aspen stand a year after collapse of an infestation by Malacosoma fragile. The stand had been completely defoliated the 3 previous years.

\section{Effects of Tent Caterpillar Defoliation on Aspen Growth}

In general, radial growth of aspen is greatly reduced with increasing intensity and frequency of defoliation. Hodson (1954) reported the radial increment of aspen during 1 year of light defoliation by the forest tent caterpillar was 90 percent of the growth 3 years earlier. Medium and heavy defoliation reduced growth to 55 percent and 24 percent of normal, respectively. Growth after 3 consecutive years of heavy defoliation was only 10 to 15 percent of normal. Radial growth of aspen in New Brunswick, Canada, was reduced 42,52 , and 77 percent during outbreaks of $M$. disstria in 1949, 1950, and 1951, respectively (Barter and Cameron 1955).
Measurements of annual rings on the increment borings from 92 aspen trees during the present study showed radial growth was reduced $28.4,52.2$, and 74.6 percent after 1,2 , and 3 consecutive years of complete defoliation, compared to the average annual growth during the preceding 6 years.

Repeated defoliation not only greatly reduced radial growth, but also significantly changed the proportion of live and dead trees, and live trees with top-kill between 1961 and 1965 (table 5). The living trees that still remained in stands $\mathrm{A}, \mathrm{B}$, and $\mathrm{C}$ were so deteriorated ( 85 to 100 percent with top-kill) that for practical purposes the stands were without biological, economic, or esthetic value (fig. $5)$.

Table 5.--Changes in the percent of live, dead, and top-killed trees in six aspen stands between 1961 and 1965

\begin{tabular}{|c|c|c|c|c|c|c|}
\hline \multirow{2}{*}{ Stand } & \multicolumn{2}{|c|}{ Alive } & \multicolumn{2}{|c|}{ Dead } & \multicolumn{2}{|c|}{ Alive but top killed } \\
\hline & 1961 & 1965 & 1961 & 1965 & 1961 & 1965 \\
\hline & 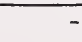 & $-\quad-$ & $--\underline{F}$ & at - - & -- & - \\
\hline $\mathrm{A}$ & 81.0 & 29.0 & 19.0 & 71.0 & 20.0 & 85.0 \\
\hline $\mathrm{B}$ & 82.8 & 47.6 & 17.2 & 52.4 & 27.3 & 100.0 \\
\hline $\mathrm{C}$ & 73.2 & 53.6 & 26.8 & 46.4 & 24.8 & 86.4 \\
\hline $\mathrm{D}$ & 78.2 & 70.4 & 21.8 & 29.6 & 16.3 & 24.2 \\
\hline $\mathrm{E}$ & 71.9 & 66.7 & 28.1 & 33.3 & 4.3 & 7.1 \\
\hline$F$ & 92.6 & 81.8 & 7.4 & 18.2 & 0 & 16.7 \\
\hline
\end{tabular}




\section{Natural Control}

\section{Parasites and Predators}

A list of the insect parasites and stage of the host attacked is presented in table 6 . A total of 17 dipterous and 17 hymenopterous species were recorded as primary parasites of M. fragile in rearings from New Mexico and Arizona. Two additional species of diptera and six hymenoptera were primary parasites of $\mathrm{M}$. fragile incurva Henry Edwards collected from $\overline{\text { Sabino }} \overline{\text { Canyon, Tucson, Arizona. }}$

Eggs.-To determine the identity and importance of egg parasites, egg masses of $\underline{M}$. fragile collected during the spring before the larvae hatched were reared individually in shell vials. Eggs that failed to hatch and hatching larvae and parasites were counted (table 7). Many of the larvae had already hatched by the time the egg masses were collected in 1961 and 1963, making it impossible to record the number of hatching larvae and consequently the number of eggs per mass during those years.

Only two species of egg parasites were recorded during the 5-year period of observation. Telenomus clisocampae Riley occurred rarely; only a few specimens were reared from one or two of the egg masses deposited in 1961 and 1963. Tetrastichus malacosomae Girault, however, was reared from 70 to 90 percent of the egg masses. The rate of parasitism varied widely between masses, ranging from 0.5 to 48.3 percent. However, total parasitism caused by $\mathrm{T}$. malacosomae reached a maximum of only 11.3 percent in 1960. Except for 1959, when the infestation was just beginning, the incidence of aborted eggs accounted for more egg mortality than T. malacosomae (table 7). Several factors that may have contributed to this increase include: (1) a general decline in population vigor brought about by limited food supplies during the development of the last instar, and/ or changes in the nutritive value of the foliage of the weakened trees, and (2) increased inbreeding among adult moths originating from the same egg mass.

The life cycle of $T$. malacosomae is well synchronized with that of the tent caterpillar. The parasite remains in the egg mass after the larvae have hatched, and does not emerge until the tent caterpillar has completed development and the adult moths oviposited, thus making new egg masses available to the parasites as they emerge. On August 14, 1962, approximately 2 weeks after peak egg deposition, swarms of T. malacosomae adults were observed on the leaves of partially defoliated open-grown aspen seedlings and on new egg masses present on the branches. Eggs located around the periphery of the mass, where the spumaline coating is thinnest, are most susceptible to parasitism.

Larvae.-Two species of hymenopterous parasites were reared from $M$. fragile larvae (table 6). An undescribed species of Rogas was by far the most widespread and common larval parasite. Larvae parasitized by Rogas can be readily distinguished from healthy larvae several days prior to death. They are noticeably stunted, with body diameter and length less than half that of normal. The parasitized larvae fade to a light yellowish color. The larvae become hard, shrunken, and mummified, usually during the fourth instar. Rogas-parasitized larvae are commonly found cemented at the anterior ventral surface to the webbing of the tent or on the branch on which the larvae have been feeding. Rogas-parasitized larvae were collected in the field as early as June 7 to as late as July 27. Adult parasites emerged from June 18 to August 23. Although a minimum of 11 days was required from the time of host death to parasite emergence, Rogas adults did not emerge in some samples until 40 days after collection. Parasitism by Rogas amounted to 7.5 percent in 1962 (based on the examination of 1,164 larvae) and 9.2 percent in 1964 (based on 250 larvae).

Habrocytus sp., Aphidius lachni Ashmead, and Tritneptis scuetellata (Muesebeck) were encountered very rarely as secondary parasites of Rogas. Habrocytus sp. was a common emergent in mass rearings of $M$. fragile pupae, where it probably occurred as a secondary parasite with cocoons of Ichneumonidae, the primary.

Bracon xanthonotus Ashmead also attacks M. fragile larvae, but since it was most commonly associated with parasites emerging from the cocoon stage, it is discussed in the following section on pupal parasites.

Pupae.-Quantitative studies were made of the pupal parasites of M. fragile in New Mexico during 1961 and 1962. A comparison of the results between the 2 years showed similar trends in parasite abundance, the proportion of dipterous to hymenopterous parasites, and in 
Table 6. --Parasites and predators of the Great Basin tent caterpillar, Malacosoma fragile and M. fragile incurva in New Mexico and Arizona

\section{DIPTERA:}

Tachinidae

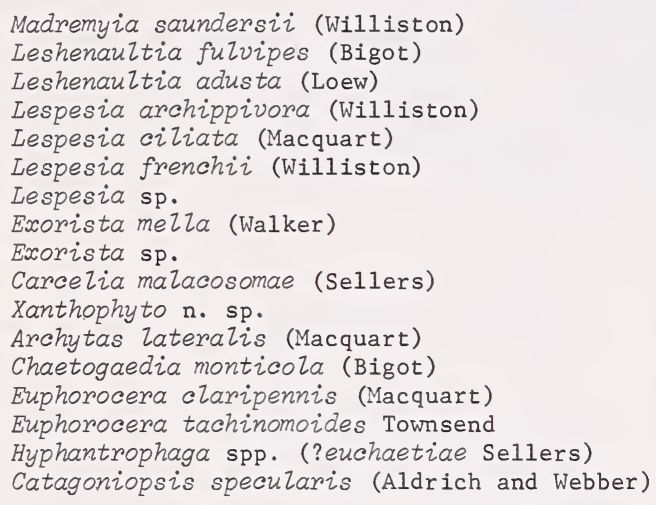

Sarcophagidae

Pseudosarcophaga affinis (Fallén)

Sarcophaga aldrichi Parker
Larva, pre-pupa, pupa Larva, pre-pupa, pupa

\section{HYMENOPTERA:}

Ichneumonidae

Pimpla pedalis Cresson

Pimpla sanguinipes (s.1.) Cresson

Pimpla sanguinipes erythropus (Viereck)

Phytodietus sp.

Theronia atalantae fulvescens (Cresson)

Itoplectis conquisitor (Say)

Itoplectis quadricingulata (Provancher)

Itoplectis viduata (Gravenhorst)

Gombrus canadensis exareolatus (Viereck)

Iseropus californiensis Cushman

Pteromalidae

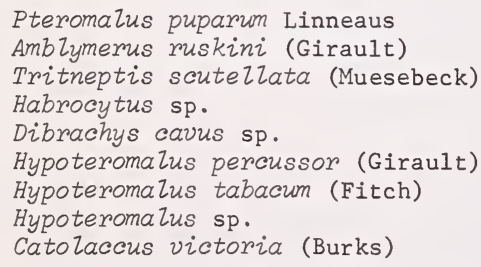

\footnotetext{
'Recorded only from MaZacosoma fragile incurva Henry Edwards - Tucson, Arizona.
}

${ }^{2}$ Recorded from both $M$. fragile and $M$. fragile incurva. 
Table 6.--(continued)

Parasites and predators

Emerged from host stage

HYMENOPTERA (continued)

Chalcidae

Brachymeria ovata (Say)

Brachymeria compsilurae (Crawford)

Pupa, Secondary on $A$. ZateraZis ${ }^{1}$

Eulophidae

Tetrastichus malacosomae Girault

Tetrastichus coerulescens Ashmead

Aphelininae sp.

$\mathrm{Egg}^{2}$

Pupa

Egg $^{1}$

Encyrtidae

Ooencyrtus clisiocampae (Ashmead)

$\mathrm{Egg}^{1}$

Torymidae

Microdontomems fromipennis Crawford

Pupa, Secondary on A. ZateraZis ${ }^{1}$

Braconidae

Rogas n. sp.

Bracon xanthonotus (Ashmead)

Larva

Aphidius Zachni Ashmead

Larvae, pre-pupa

Secondary on Rogas

Scelionidae

Telenomus clisocampae Riley

Sphecidae

Podalonia occidentalis viurrary

Larval predator

HEMIPTERA:

Reduviidae

Apiomerus sp.

Larval predator

Table 7. --Mortality of Malacosoma fragile eggs

\begin{tabular}{|c|c|c|c|c|c|c|}
\hline $\begin{array}{c}\text { Year } \\
\text { deposited }\end{array}$ & Examined & Parasitized & Per mass & Parasitized & Aborted & Mortality \\
\hline 1959 & 40 & 70.0 & 162.3 & 8.3 & 1.8 & 6.2 \\
\hline 1960 & 18 & 89.9 & 122.6 & 13.9 & 21.4 & 28.8 \\
\hline 1962 & 82 & 87.8 & 141.5 & 10.4 & 25.5 & 25.3 \\
\hline 1963 & 113 & 85.8 & 0 & 9.6 & 19.8 & -- \\
\hline
\end{tabular}


total pupal mortality (table 8 ). Parasite activity visibly increased as the summer progressed. The timing of collections is critical to an accurate appraisal of pupal parasites. Collections in June and July were obviously taken before the parasite attack period was completed while the mid-August collection was too late as many of the parasites had already emerged from their host. In general, the levels of pupal mortality were low as compared to observations of parasitism during outbreaks of other tent caterpillars. During a forest tent caterpillar outbreak in Minnesota, parasitism increased from 35 percent in 1936 to 60 to 100 percent in 1937 (Hodson 1941). Sippell (1958) determined the cocoon parasitism by Sarcophaga aldrichi Parker was 77.5 percent during the fifth year of an outbreak of this insect in Ontario, and individual collections ran as high as 90 percent.

Pseudosarcophaga affinis (Fallen) and Sarcophaga aldrichi Parker, two principal dipterous parasites accounted for 81 percent of the parasitism by diptera in 1961 and 74 percent in 1962 (table 9). The occurrence of S. aldrichi dropped sharply in 1962 with P.affinis assuming the dominant position. Madremyia saundersii (Williston), a well known parasite of the spruce budworm, Choristoneura fumiferana Clements, accounted for 13 percent of the dipterous parasitism in 1962, although it was not recorded in 1961

Several species of dipterous parasites were reared from cocoons of $\mathrm{M}$. fragile collected in 1961 from Rhus trilobata Nutt. at Los Alamos,
New Mexico. Although quantitative figures were not obtained, Archytas lateralis (Macquart) was the most abundant parasite followed by Euphorocera tachinomoides Townsend, E. claripennis (Macquart), Lespesia frenchii

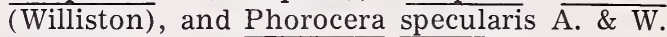
A. lateralis was also the most important pupal parasite of the tent caterpillar, M. fragile incurva Henry Edwards, infesting cottonwood and willow in Sabino Canyon near Tucson, Arizona in 1963. It accounted for over 75 percent of all dipterous parasitism, and for 16.6 percent of total pupal mortality' (Stelzer 1966). The above observations on the abundance of A. lateralis at Los Alamos and at Sabino Canyon indicate that introduction of this parasite into $M$. fragile infestations in northern New Mexico might be advantageous.

Three ichneumonids, Pimpla pedalis Cresson, Theronia atalantae fulvescens (Cresson), and Itoplectis viduata (Gravenhorst) represented 76 percent of the hymenopterous pupal parasites in 1961 (table 9). All three species showed a preference to emerge from the anterior end of the host pupa, ranging from 63 percent for $\mathrm{T}$. atalantae fulvescens to 86 percent for P. pedalis and 69 percent for I. viduata. The occurrence of $\mathrm{T}$. atalantae fulvescens and $\mathrm{I}$. viduata decreased in 1962 with P. pedalis and the braconid, Bracon xanthonotus (Ashmead) both increasing. Pimpla pedalis and T. atalantae fulvescens were reared from pupal collections made as early as June 28 to as late as August 15 during both years. Parasite emergence took

Table 8.--Percent mortality of Malacosoma fragile cocoons collected periodically during 1961 and 1962

\begin{tabular}{|c|c|c|c|c|c|c|}
\hline Date collected & Cocoons & Diptera & Hymenoptera & $\begin{array}{c}\text { Adult moth } \\
\text { dead in cocoon }\end{array}$ & Unknown & Total mortality \\
\hline
\end{tabular}

$1961:$

$\begin{array}{lrrrrrr}\text { June } 28 & 258 & 1.6 & 1.9 & 0 & 9.7 & 13.2 \\ \text { July } 19-26 & 2,265 & 12.9 & 5.5 & 5.6 & 6.3 & 30.3 \\ \text { August } 15 & 638 & 18.0 & 9.9 & 4.9 & 15.5\end{array}$

$1962:$

$\begin{array}{lrrrrrr}\text { June } 14-26 & 1,892 & 3.1 & 3.0 & 2.0 & 6.8 & 14.9 \\ \text { July 3 } & 830 & 7.7 & 4.0 & 2.9 & 5.2 & 19.9 \\ \text { July 24 } & 1,027 & 11.0 & 3.1 & 6.2 & 4.8 & 25.1 \\ \text { August } 8 & 1,191 & 26.2 & 9.2 & 2.8 & 1.7 & 39.9\end{array}$


Table 9. --Occurrence of dipterous and hymenopterous parasites of Malacosoma fragile, 1961-62, Carson National Forest, Tres Piedras, New Mexico

\begin{tabular}{|c|c|c|c|c|c|}
\hline \multirow{2}{*}{ Parásite and species } & \multicolumn{2}{|c|}{ Parasitism } & \multirow{2}{*}{ Parasite and species } & \multicolumn{2}{|c|}{ Parasitism } \\
\hline & 1961 & 1962 & & 1961 & 1962 \\
\hline \multicolumn{4}{|c|}{ Percent } & \multicolumn{2}{|c|}{ Percent } \\
\hline DIPTEROUS: & & & HYMENOPTEROUS: & & \\
\hline Pseudosareophaga affinis & 39 & 55 & Pimpla pedalis & 14 & 23 \\
\hline Sarcophaga aldrichi & 42 & 19 & Pimpla sanguinipes & 3 & 0 \\
\hline Lespesia frenchii & 7 & 3 & Theronia atalantae fulvescens & 40 & 15 \\
\hline Carcelia malacosomae & 5 & 9 & Bracon xanthonotus & 13 & 53 \\
\hline Madremyia saundersii & 0 & 13 & Itoplectis viduata & 22 & 7 \\
\hline Leshenaultia fulvipes & 2 & 0 & Itoplectis conquisitor & 6 & 0 \\
\hline Exorista mella & 3 & 0 & Itoplectis quadricingulata & 1 & 0 \\
\hline Xanthophy to sp. & 1 & 0 & Gombrus canadensis exareolatus & 0 & 1 \\
\hline \multirow[t]{2}{*}{ Other } & 1 & 1 & Other & 1 & 1 \\
\hline & 100 & 100 & & 100 & 100 \\
\hline
\end{tabular}

place from July 14 to September 5, a sufficient interval of time to permit these species to develop more than a single generation.

Bracon xanthonotus Ashmead was by far the most abundant hymenopterous parasite of the tent caterpillar. This parasite was observed making its attack on mature larvae just after they began construction of the cocoon. Eggs are laid on the body of the host by the female, and hatch in 1 to 2 days. The parasite larvae feed through the integument of the caterpillar (fig. 6a). The parasite pupae are formed in small whitish cocoons in clusters on the body of the host (fig. 6b). B. xanthonotus accounted for 8.8 and 6.0 percent parasitism of Augustcollected cocoons during 1961 and 1962, respectively. Individual rearing records, maintained on 55 cocoons parasitized by $\underline{B}$. xanthonotus in 1962, showed the number of parasites emerging from each host ranged from 1 to 102, with an average of $33.1 \pm 3.4$ ( $\mathrm{S}$. E. Mean). Parasites emerged as early as July 17 and as late as August 22. Maggots of the dipterous parasite, P. affinis, emerged from 21.8 percent of the hosts parasitized by B. xanthonotus.

Up to 6.2 percent adult mortality was observed in the pupal case. In several instances the dead adults were found to contain maggots of Pseudosarcophaga affinis (Fallen). Although many of the dead adults were mascerated, all examinations for viral infection proved negative.

\section{Microbial Control}

Tent caterpillars in the genus Malacosoma have long been known to be susceptible to lethal infection by polyhedroses (Chapman and Glaser 1915). Clark (1955, 1958) reported the termination of an outbreak of $M$. fragile due to an epizootic of a polyhedral virus. Generally, an epizootic occurs only after the insect has been present at high population densities for several consecutive years. By this time, feeding by the insect has usually caused extensive damage to the host. During recent years, the artificial introduction of disease-producing microorganisms into apparently disease-free areas has often established the pathogen and effectively controlled the pest.

Field tests of virus and the bacterium against M. fragile in New Mexico (Stelzer 1965) showed that: (1) the rate of mortality increased with dosage, (2) young larvae were more susceptible 
Figure 6.--Bracon xanthonotus (Ashmead), a parasite of mature Zarvae of $M$. fragize:
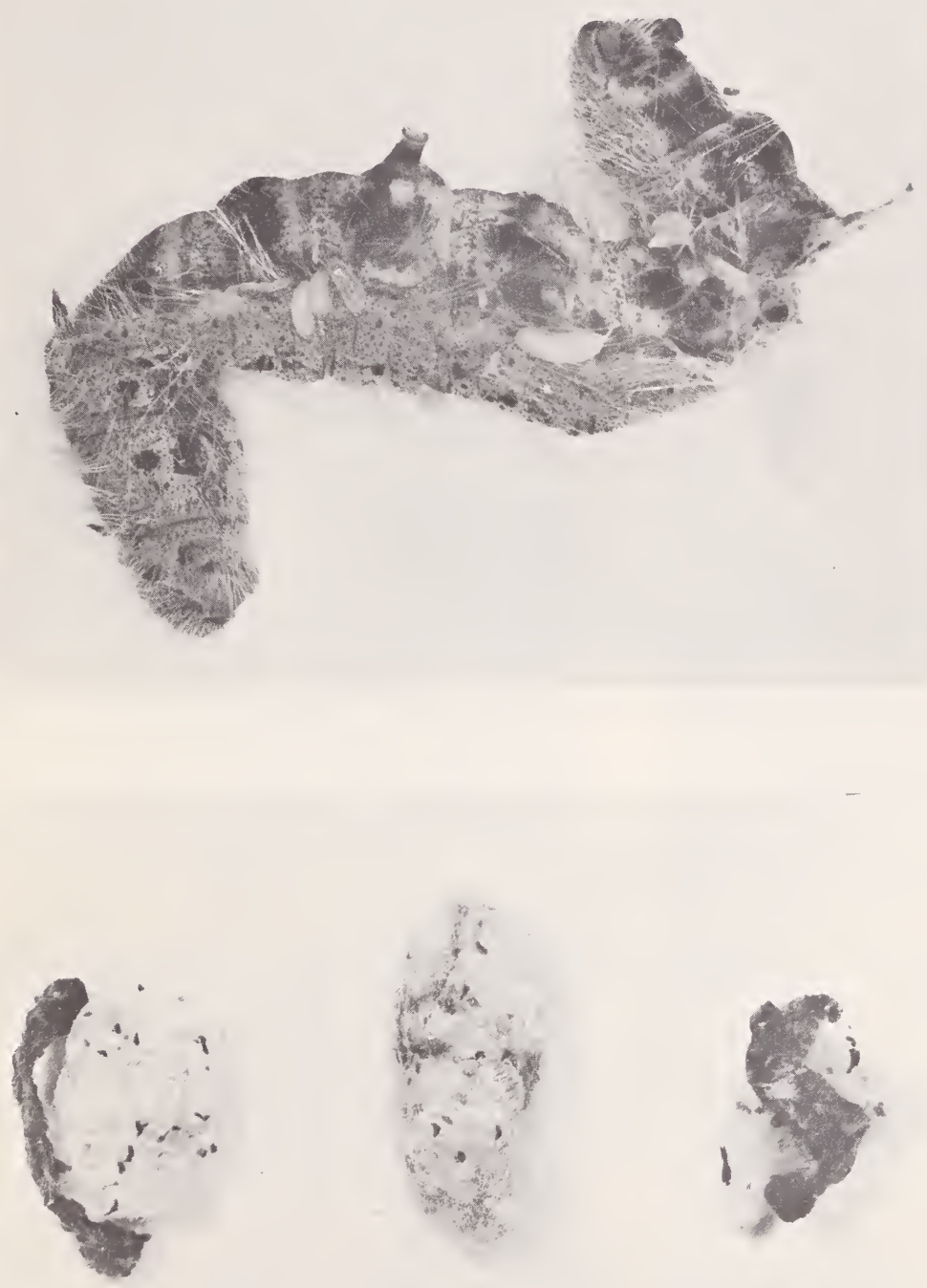
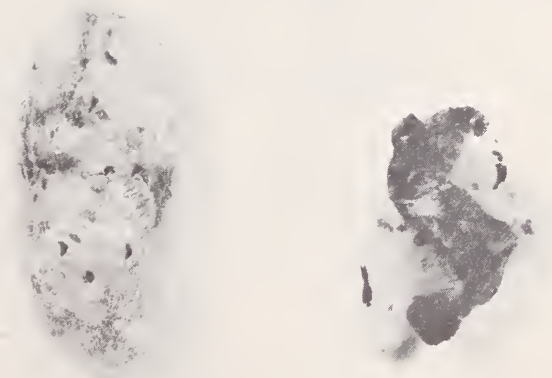

A, Parasite Zarvae feeding through integument of host.
$B$, Typical clusters of parasite cocoons. (scale ine $=1$ inch) 
to lethal infection than were older larvae, and (3) treatments containing both pathogens in combination were more effective than either agent alone. Aerial applications of the two pathogens in combination resulted in a high rate of infection of colonies of $M$. fragile incurva in Arizona 2 to 3 weeks after application (Stelzer 1966). Populations were 95 percent lower in the sprayed area than in an untreated area the year following treatment.

In tests to control $\mathrm{M}$. fragile infesting aspen reproduction (up to 2 inches d.b.h.) the following treatments were applied:

1. Thuricide $W^{3}$ containing 30 billion viable spores of Bacillus thuringiensis per gram at

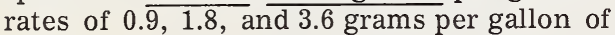
water.

2. M. fragile virus collected locally and also M. fragile virus collected locally but propagated in larvae of the eastern tent caterpillar, M. americanum (Fabricius) at rates of $1 \times \overline{10}^{8}$ and $2 \times 10^{8} \mathrm{poly} / \mathrm{ml}$ of water.

3. Untreated control.

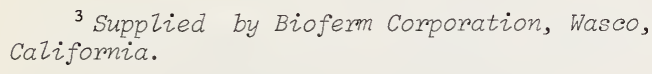

${ }^{3}$ Supplied by Bioferm Corporation, Wasco, California.

Table 10. - Mean weight of female and male pupae of the Great Basin tent caterpillar surviving Table 10. --Mean weight of female and male pupae of the Great Basin
treatments with virus and Thuricide WP ${ }^{1}$
The treatments were applied to three trees with a Model 2010 Bean sprayer (1-1/2 gallon capacity). At the time of treatment some of the larvae had already started to pupate. Estimates of defoliation were recorded on the experimental trees at the time of application of the treatments and again 20 days later when the larvae had pupated.

Defoliation of the virus-treated and untreated control trees increased from about 50 percent to over 95 percent during the 20-day interval, while the Thuricide-treated trees exhibited but a slight increase from 55 to 65 percent in the level of defoliation. Pupal counts averaged 45,77 , and 160 per tree in the virus, Thuricide, and control tests, respectively. A collection of the surviving pupae were reared individually in cotton-stoppered test tubes with the pupal weight in milligrams being recorded along with treatment (that is, from virus, Thuricide, or untreated control trees). Upon emergence, the sex of the adult moths was combined with the pupal weight and treatment (table 10). An analysis of variance for treatment effect on the female pupal weights was highly significant $(F=5.53)$. Comparison of the means among the eight treatments by Duncan's multiple range test showed the mean weight of

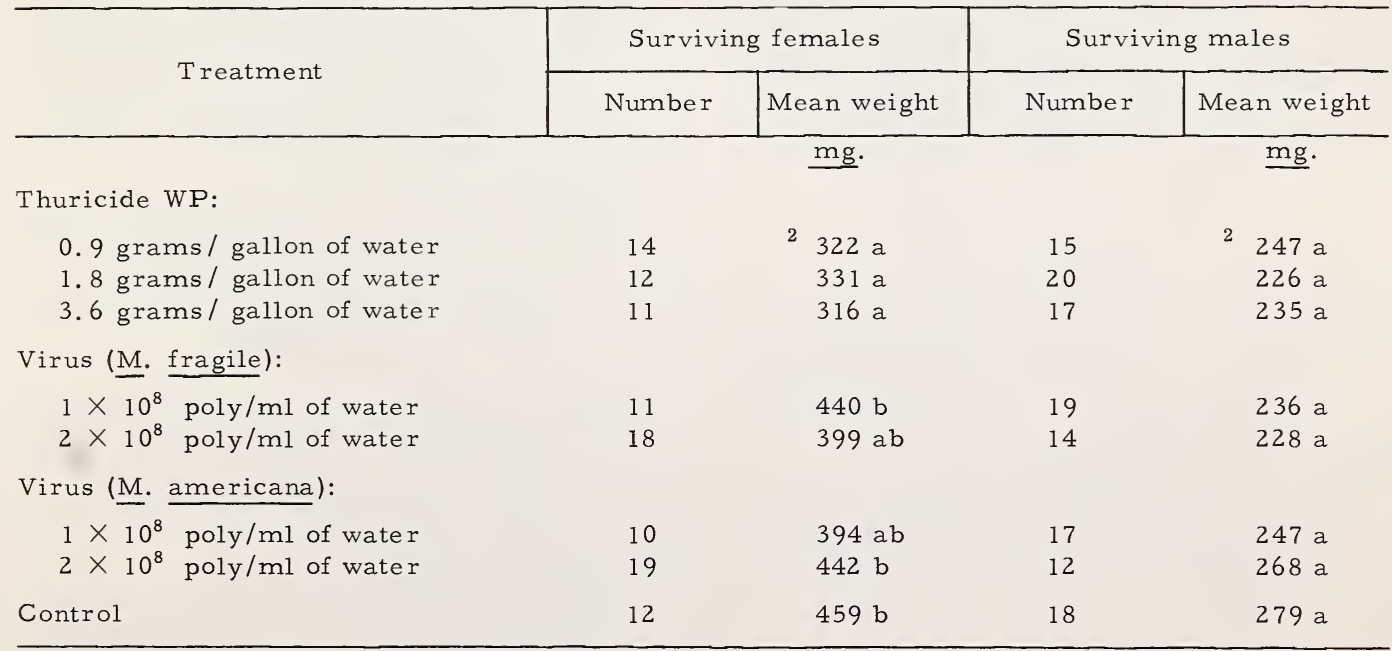

${ }^{1}$ Containing 30 billion viable spores of Bacillus thuringiensis per gram.

${ }^{2}$ Quantities with a common letter are not significantly different at the 5 percent level, according to Duncan's multiple range test. 
female pupae collected from the control trees to be significantly higher $(0.05$ level $)$ than the pupae from the Thuricide-treated trees, but not significantly higher than any of the virus treatments (table 10).

A reduction in female pupal size following exposure to Bacillus thuringiensis could have a significant effect on the trend of an infestation. McKnight (1967) determined the fecundity of a female moth of the western budworm, Choristoneura occidentalis Freeman, was significantly related to the size of her pupa; the moths from larger pupae laying more eggs than from smaller pupae. In the case of the tent caterpillar, smaller egg masses would also have a higher proportion of marginal eggs, where the spumaline coating is thinnest, and the eggs are most susceptible to parasitism.

Male pupal weights were not significantly different, most likely because the treatments were applied very late during the season when some larvae were already beginning to pupate. Male larvae apparently complete their development and begin to pupate earlier than female larvae. For example, male moths emerged from 63 percent of 276 pupae collected on June 19, 1961 , the earliest date pupation was observed in the field. Overall, male moths emerged from 56 percent of 2,150 June-collected pupae compared with 48 percent of 3,095 July-collected pupae, in 1961-62 combined.

During the present study, naturally occurring polyhedrosis epizootics were recognized as the primary reason for the termination of $M$. fragile populations in stands D and F. Aerial applications of virus in 1958 appeared to provide effective protection against reinfestation in stand $\mathrm{E} 6$ years after treatment.

\section{Literature Cited}

Barter, G. W., and Cameron, D. G.

1955. Some effects of defoliation by the forest tent caterpillar.* Can. Dep. Agr. Forest Biol. Div. Bi-monthly Progress Report 11(6): 1 .

Chapman, J. W., and Glaser, R. W.

1915. A preliminary list of insects which have wilt, with a comparative study of their polyhedra. J. Econ. Entomol. 8: 140-149.

*Address requests for copies to originating office.
Clark, E. C.

1955. Observations on the ecology of a polyhedrosis of the Great Basin tent caterpillar, Malacosoma fragilis. Ecology 36: 373-376.

1958. Ecology of the polyhedroses of tent caterpillars. Ecology 39: 132-139.

Hodson, A. C.

1941. An ecological study of the forest tent caterpillar Malacosoma disstria Hbn. in northern Minnesota.* Minn. Agr. Exp. Sta. Tech. Bull. 148, 55 pp.

1954. Forest tent caterpillar: populations, effect of defoliation, and control. Entomol. Soc. Amer. N. Central States Br. Proc. 9: 35-36.

and Weinman, C. J.

1945. Factors affecting recovery from diapause and hatching of eggs of the forest tent caterpillar Malacosoma disstria Hbn.* Minn. Agr. Exp. Sta. Tech. Bull. $170,31 \mathrm{pp}$.

List, G. M.

1934. Entomological Report. Report for Colorado. Calif. Agr. Mo. Bull. 23: 236. McKnight, Melvin E.

1967. Ecology of the western budworm, Choristoneura occidentalis Freeman (Lepidoptera: Tortricidae), in Colorado. Diss. Abstr. 28: 1977B. (Ph.D. thesis. Colo. State Univ., Fort Collins, 1967.) Sippell, W. L.

1958. A study of the forest tent caterpillar Malacosoma disstria Hbn. and its parasite complex in Ontario. Diss. Abstr. 18: 1549. (Ph.D. thesis, Univ. of Mich., Ann Arbor, 1957.)

Stelzer, M. J.

1965. Susceptibility of the Great Basin tent caterpillar, Malacosoma fragile (Stretch), to a nuclear-polyhedrosis virus and Bacillus thuringiensis Berliner. J. Invert. Pathol. 7: 122-125.

1966. Control of a tent caterpillar, Malacosoma fragile incurva, with an aerial application of a nuclear-polyhedrosis virus and Bacillus thuringiensis. J. Econ. Entomol. 60: 38-41.

Thompson, C. G.

1958. A polyhedrosis virus for control of the Great Basin tent caterpillar, Malacosoma fragile. Trans. 1st Int. Conf. Insect Pathol. Biol. Control, Praha, 1958, pp. 201-204. 


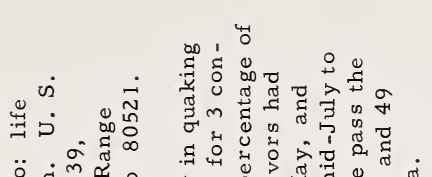

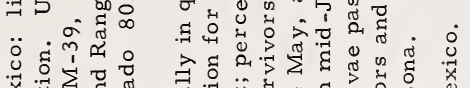

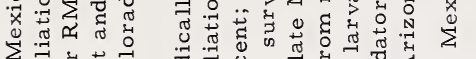
क्षे

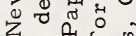
.

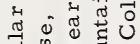

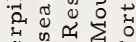

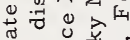
0 का 50 :

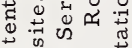
द्व का 闭看 . वृ $\begin{gathered}0 \\ 0\end{gathered}$ 考

$\therefore \infty$

ำ

is

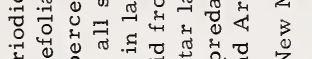

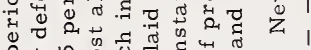

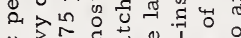

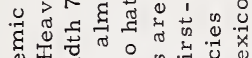

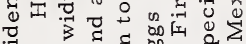

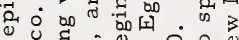

n.

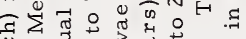

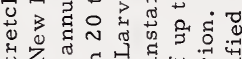

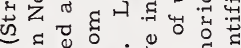

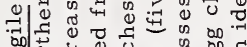

and

ज्ञात्र

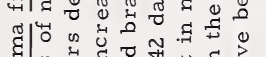

को

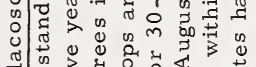

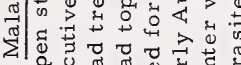

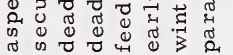

$\begin{array}{c:c}\text { in } & 1 \\ 0 & 1 \\ 0 & 1 \\ 0 & 1 \\ 3 & 1\end{array}$

ते।

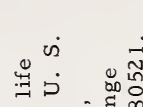

o

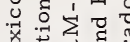

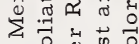

3 पै 0 की

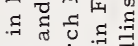

बิ

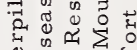

क्ष

可 0

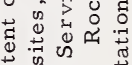

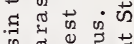

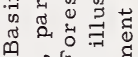

.

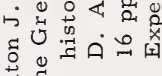

运

si

i⿱ 龰己
خ 0 क

$\infty$, 㟧

ปี

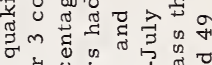

द्व 0 范

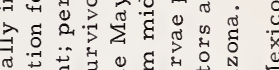

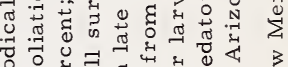

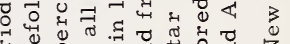

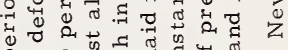

a, $>$ in

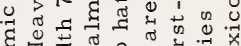

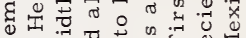

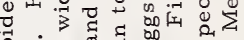

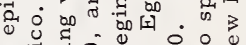

n

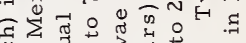

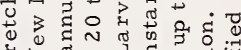

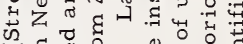

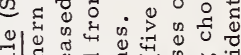

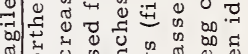

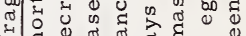

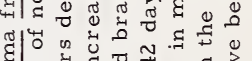

वृण की
齐

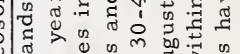

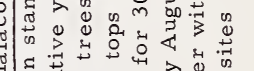

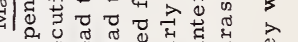
की

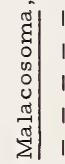

कृ

$\approx$

त्

,

$\begin{array}{ll}0 & 1 \\ 0 & 1 \\ 0 & 1 \\ 0 & 1\end{array}$

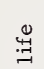

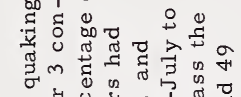

。듀

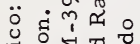

$\vec{x} \geqslant \overrightarrow{0}$

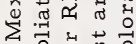

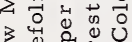

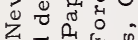

. ⿷匚⿱

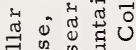

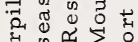

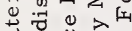

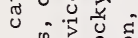

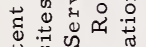

का

党

की 0 : न है

त

म

莹

iे कू

N 2

is
द्न

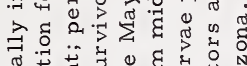

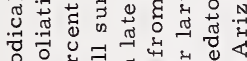

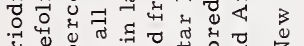

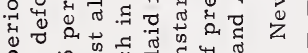

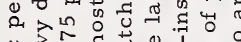

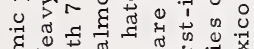

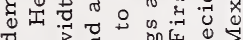

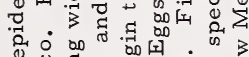

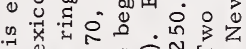

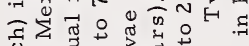

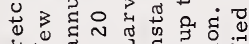

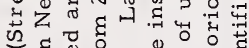

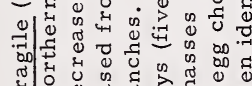

弯|

हूँ।

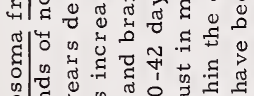

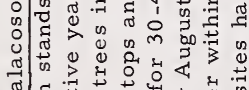

贾|

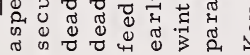

- 1,40

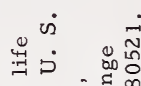

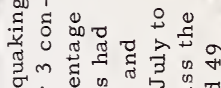

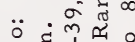

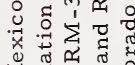

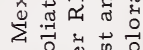

3 के है

乙一⿻上丨

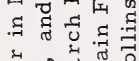

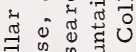

年

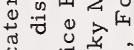

ช

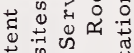

至究

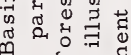

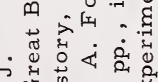

म

焉

in 1 is

si

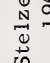




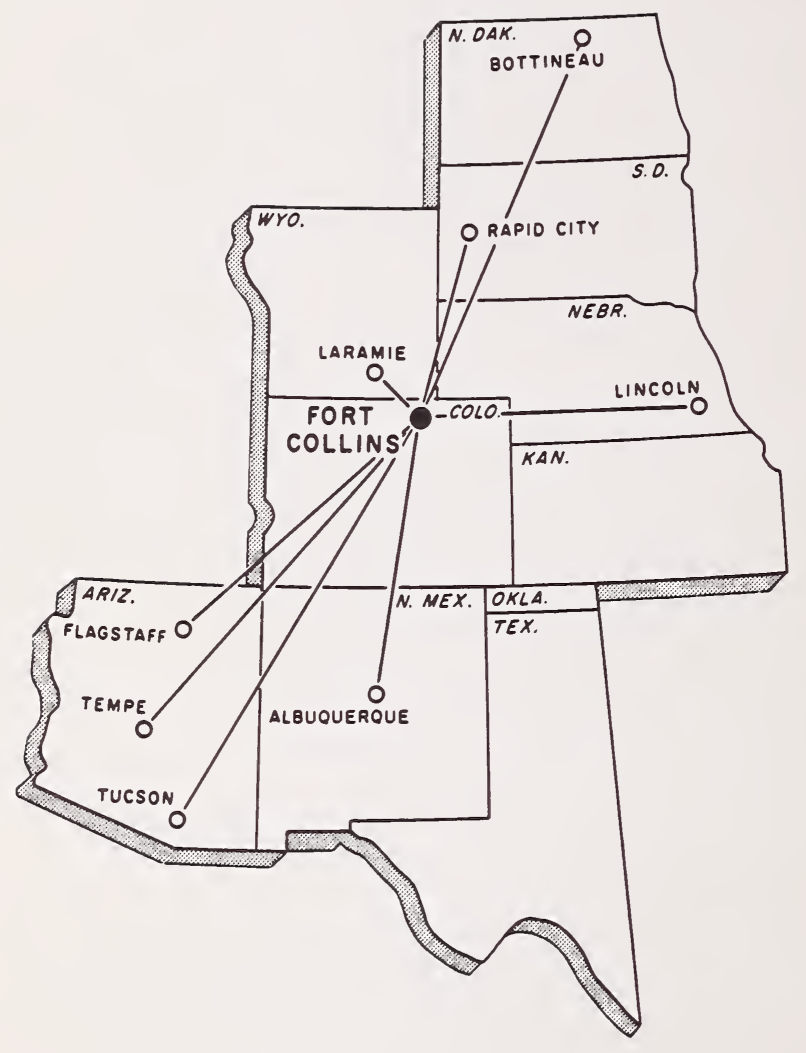

